\title{
Safety and efficacy of an add-on therapy with curcumin phytosome and piperine and/or lipoic acid in subjects with a diagnosis of peripheral neuropathy treated with dexibuprofen [Erratum]
}

Di Pierro F, Settembre R. J Pain Res. 2013;6:497-503.

Please note that throughout the article the use of the word "phytosome" should have been "Phytosome" ${ }^{\circledR}$, and the word "Meriva" should have been "Meriva ${ }^{\circledR}$ ". Phytosome ${ }^{\circledR}$ and Meriva ${ }^{\circledR}$ are trademarks duly registered by Indena Spa, Milan, Italy.

The Journal of Pain Research is an international, peer-reviewed, open access, online journal that welcomes laboratory and clinical findings in the fields of pain research and the prevention and management of pain. Original research, reviews, symposium reports, hypothesis formation and commentaries are all considered for publication.
The manuscript management system is completely online and includes a very quick and fair peer-review system, which is all easy to use. Visit http://www.dovepress.com/testimonials.php to read real quotes from published authors. 